\title{
BUSINESS ANALYSIS AND DESIGNING MODELS OF GOVERNANCE AND ALSO RISK MANAGEMENT FOR FINTECH AS EFFORTS OF FINANCING OPTIMIZATION IN MSMES
}

Putu Prima Wulandari, SE., MSA., Ak.

Anita Wijayanti, SE., MSA.,Ak

Rizka Fitriasari, SE.,MSA.,Ak

\begin{abstract}
The development of financial services based on technology or Financial Technology (Fintech) potentially gives a great contribution for Indonesia's economy. Fintech is able to draw both investor and MSMEs business administrator together that need credit loans with easier requirements compare to conventional financial institutions. The purpose of this research is to find out the readiness of MSMEs for the service offered by Fintech related to financing activity, to find out the role of fintech towards MSMEs development and national financial system, and also to find out which governance and risk management model that suits Fintech's business field. Qualitative descriptive research method is used in this research with semi structured documentation and interview data collection technique to collect primary and secondary data. Data analysis technique used in this research is content analysis from various sources, including text source, survey result and interview result. The research result shows that the majority of MSMEs
\end{abstract}


doers, about $81,8 \%$ of total respondents are absolutely ready in utilizing Fintech service. However, in this case, regulator needs to consider socializing the use of fintech in transaction process towards MSMEs to optimize the role of fintech as alternate financial source for MSMEs. The research result shows that model design of fintech governance and risk management in this research should adopt IT governance framework that includes strategic alignment, trust value delivery, resource management, business \& IT risk management and performance management. Besides that, big data management also becomes part of fintech business governance and risk management model design.

\section{Keywords: MSMEs, Fintech, IT Governance, Risk management, Big Data}

\section{INTRODUCTION}

Innovations in information technology have spawned the Financial Technology (Fintech) business to accommodate new market not been explored by conventional banking. Emergent usage of Fintech services in the midst of society can not be separated from the widespread technology that is familiar to society itself nowadays. Information technology can facilitate the society in remote areas to access financial services. Currently nearly entire Indonesia's population is able to enjoy the technology. It is interpreted as digital revolution whose main driver is digital technology revolution. This occurs in wholly business sectors, nevertheless due to its implemenattaion in financial sector it is 
called Fintech which is an acronym of financial and technology (Hanantasena, 2016).

The ease provided by Fintech service is not just consumers can make transactions without visiting the office or meeting the service providers directly, but also they can have unsecured loans, which add more value for Fintech services than other banking sector. Of course for MSMEs businesspeople it is not problematic to transact online in which sector they mostly trade their products in online stores and marketplace. On the other hand, the penetration of technology is nearly equally distributed all over Indonesia, in other words, people nowadays have the same access related to information technology.

This convenience is positively worthy opportunity for MSMEs businesspeople who get difficulty in gaining funding access from formal financial institutions. Fintech has the potential to turn into alternative funding source for MSMEs to fortify their establishment on financial side, which in turn will be able to boost the national economy.

Bank Indonesia (BI) notes Fintech's existence is progressively substantial exclusively in the past couple years. Indonesia Fintech Survey 2016 indicates that in Indonesia 78\% of total Fintech players start their business by 2015. By the end of 2016, there are 142 Fintech companies in four diverse categories. In Indonesia Fintech is engaged in Deposit, Lending and Capital Raising. They also engage in Payments, Clearing and Settlements, Investment and Risk Management and Market Provisioning. Among these categories, FintechPayments and FintechLending have the prime share of the number of businesspeople, i.e. 74\% (Linangkung, 2017). 
By utilizing unconventional technology and method, Fintech company can provide business capital loans by analyzing MSME applicants faster and more precisely with prudential principles. Through technology-based services, Fintech brings together businesspeople, who need capital loan, to interested investors funding capital. Previously funding MSMEs businesspeople is very risky nonetheless Fintech makes it possible for transaction costs to be very small and efficient (Mulyani, 2016)

Diverse characteristics between Fintech's and corporate business encourage the necessity for adjustment of governance models. On the other hand, Fintech growth in Indonesia takes place on the basis of consumers, customers and merchants needs, in which Fintech nature is mere user centric so it focuses more on its users. Consumer protection issues, therefore, become concern Fintech needs further regulations. In other words, regulation makes Fintech obliged for transparency to consumers, such as Fintech risk and risk management. Scott (2007) reveals that good governance guarantees the company to achieve its desired goals, lower cost of fund, and attract new players, which in turn it rises competition. In this case, government should make intervention to arrange the supervisory mechanisms in business practices, in form of governance and risk management. Government regulates Fintech's operational activities so as to be more efficient towards high competitiveness and avoid potentially moral hazardous practices.

Regarding the growing speed of industry, regulators must be aware of arising potential of systemic risks due to the industry high achievement. In this case regulators must evaluate procedures to ensure consumer protection and strive to deal with information asymmetry in Fintech business practices in order to decrease the consumer investment risk. Therefore, it is necessary to manage good business practices so that Fintech's business sector can upsurge its role in encouraging the growth of MSMEs business and the national economy. Business 
analysis in this study is conducted to the consideration in designing a model of governance and risk management, but at first researcher must carry out initial mapping for Fintech role and risk including the MSMEs businesspeople readiness towards Fintech's services. Based on the background presented earlier, researcher is interested in conducting study on the model design of Fintech's corporate governance and risk management that initiates with Fintech business analysis.

Research problem in this study are as follows

1. How is MSME's readiness for online-based financial services offered by Fintech?

2. What is Fintech's role in the growth of MSMEs and national financial system?

3. How does Fintech's model for governance provide financial services for MSMEs?

4. What is the model design of Fintech's risk management in providing financial services for MSMEs?

The objectives of this study are as follows:

1. To identify the readiness of MSMEs to online-based financial services offered by Fintech.

2. To understand Fintech's role in the development of MSMEs and national financial system.

3. To find out how the model design for Fintech's governance in providing financial services for MSMEs.

4. To discover how the model design for Fintech risk management in providing financial services for MSMEs. 
Contribution of the study:

1. Theoretical contribution

This study is expected to contribute to the theory development of good governance and risk management in technology-based financial services sector in the era of digital economy.

2. Practical contribution

This study is expected to contribute to the manifestation of sound business practices for Fintech service providers through good governance and apt risk management as an effort to fortify MSME from financial side, improve fintech efficiency, minimize transaction costs and minimize cost of regulation.

3. Policy contribution

This Study is expected to contribute to policy making related to Fintech business governance and risk management in providing financing to MSMEs and as an effort to fortify MSME's financial institutions.

\section{LITERATURES REVIEW}

\section{Fintech in Indonesia}

In 2016 study results from Bank Indonesia revealed that, in Indonesia, there are rapidly increasing Fintech's growth where Fintech's transaction value is estimated to reach USD 14.5 billion, or $0.6 \%$ of total global transaction value, estimated at USD 2,355,9 billion. 2016 Fintech Indonesia survey results, Fintech development in the country has reached $78 \%$ in 2016 and most of the payment service, by 43\% (Bank Indonesia, 2016).

In Indonesia Fintech can be divided into several groups, namely:

1. payment channel / system, ie electronic services that substitute real money and bank deposit as a means of payment 
2. digital banking, digital technology to meet customer needs such as ATM, EDC, internet banking, mobile banking, SMS banking, phone banking and video banking

3. online / digital insurance, insurance services for customers by utilizing digital technology

4. Crowdfunding, fund-raising activities through websites or other digital technologies for investment or social purposes

5. Peer-to-Peer (P2P) Lending, a financial service that utilizes digital technology to bring together between parties in need of loans and those willing to lend.

Fintech carry remarkable contributions particularly in informal sector as well as among Small and Medium Enterprises (MSMEs) (OJK, 2016). It is supported by the study conducted by Safira (2016) since the penetration of smartphone technology is so deep in Indonesia, it opens its own opportunity in banking services industry. Supported by the masterplan of mobile infrastructure development, FinTech existence becomes the answer to the financial inclusion challenge in Indonesia.

\section{Concept of Governance}

The existence of stakeholders will lead to information inequality, as described in stakeholder theory. Stakeholder theory is a theory that describes to whichever company is responsible (Freeman, 2001). The company must maintain relationships with its stakeholders by accommodating the wants and needs of its stakeholders, especially stakeholders who have power over resources availability used for company's operational activities, eg labor, market for company products and others (Ghozali and Chariri, 2007). In accordance with this theory, Fintech 
management will be the party that has more power compared to other stakeholders such as businesspeople (MSMEs) and Investors.

\section{Fintech Risk Management}

According to the Financial Services Authority (OJK) (2016) there are four risks that overshadow financial services business by technology-based companies or financial technology (fintech) that need to be aware of. The first risk in fintech business is the risk of being attacked by hackers. Second, the risk of default for fintech whose business is the intermediary of financing or credit. Third, the risk of fraud. Fourth is the vulnerability to misuse client data.

Studies conducted by Ancri in 2016 stated that there are risks and opportunities existing in fintech. Here are the risks and opportunities:

Figure 3: Fintech Risks and Opportunities

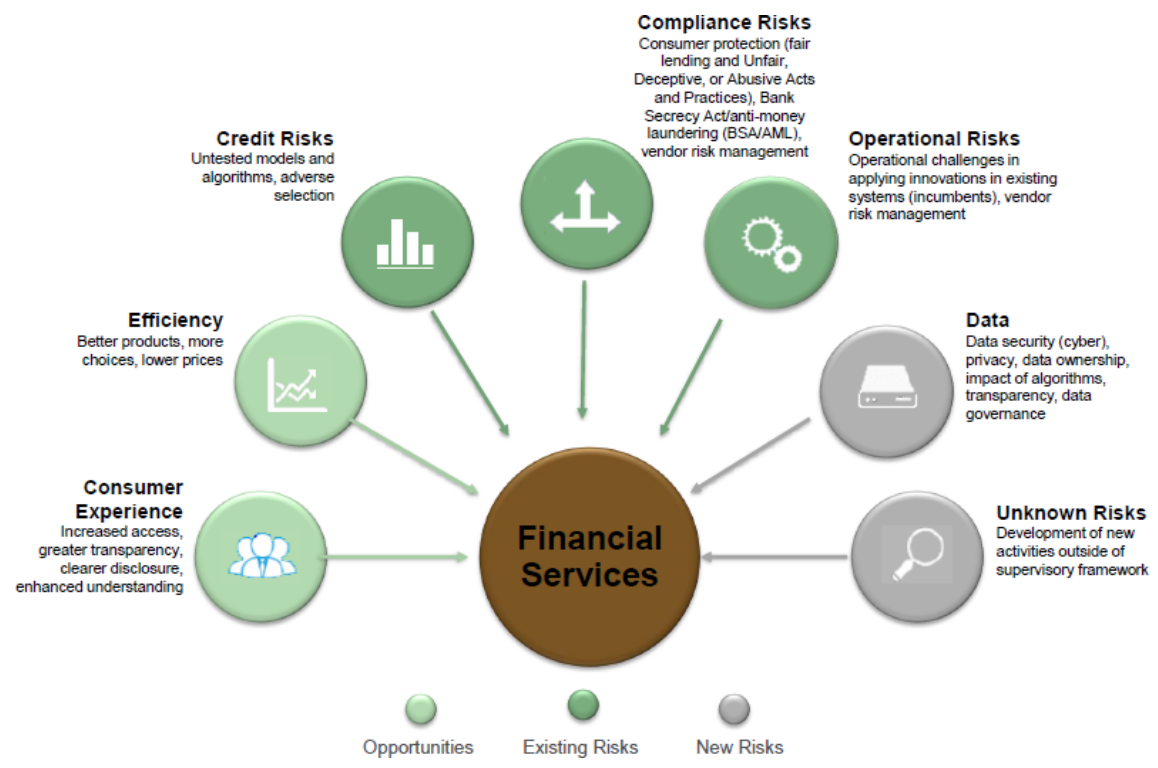

Source: Ancri (2016) 
From these studies, it is acknowledged that there are several opportunities and risks arising from fintech in which the risk of Fintech is divided into several parts, namely credit risk, compliance risk, operational risk, data and risks that are still unknown.

\section{Business Analysis}

According to Subramanyam and John (2010) business analysis is process of evaluating the economic and risk prospects of a company. It includes an analysis of the company's business environment, its strategy, and its financial position and performance. It is valuable in numerous business decisions.

Business analysis in this study is conducted by mapping Fintech prospect particularly related to its role on MSMEs development in terms of its funding, MSMEs readiness in taking its services and its position in the map of national financial system. The risks identification as an effort to establish fintech risk management model also became part of the business analysis in this study

\section{Big Data}

The term of big data, emerged since 2005, was introduced by O'Reilly Media. Nevertheless the use of data and the need to understand have been essentially around for a long time. Chandarana and Vijayalakshmi (2014) expresses that many people tried to define Big data. Big data is a generalization of numerous data, such as online transactions, all forms of social media, and many more. Big data has three main components as shown below: 


\section{Figure 4: Component of Big Data}

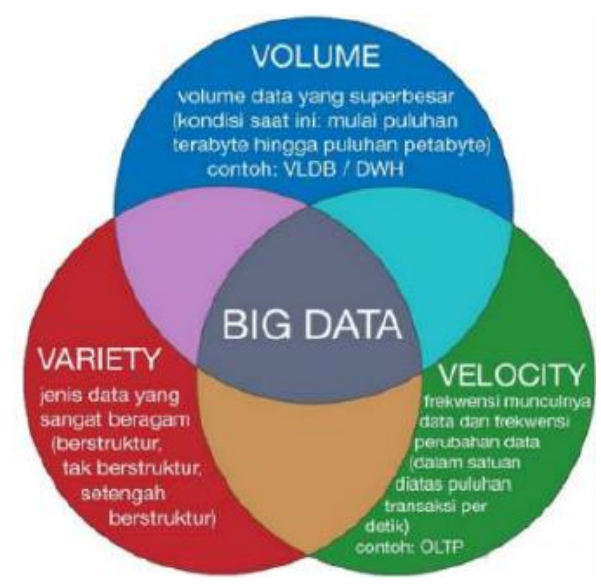

Source: IBM, 2017

\section{RESEARCH METHOD}

The qualitative approach being used in this study is in purpose of describing Fintech's business analysis, governance and risk management, in which data was obtained from various sources of information, both primary and secondary, which eventually the description can be mapped in form of research output as designed model of governance and risk management. According to Bogdan and Taylor (1975) cited by Moleong (2007: 4) states that qualitative methodology, as a research procedure, produces descriptive data in form of oral or written from the observed people and behavior. Therefore, this study uses descriptive approach that offers watchful depiction of particular individual or group about the occuring circumstances and symptoms (Koentjaraningrat, 1993: 89). The study focus on analysis unit is the content (words, meanings, photos, themes and ideas), survey results, including resukts from structured interviews. The intended informants for primary data retrieval process are academics, practitioners, and Fintech's consumers / users specifically of those who have 
MSMEs business. Secondary data collection method of this study is content documentation taken from book, magazine, newspaper, article, journal or other data source. In addition, primary data of this study were collected through semistructured interview techniques and survey methods. The data analysis technique of this study is content analysis. Content analysis method is principally a systematic technique for analyzing messages content and processing messages, or a device for observing and analyzing the contents of open communication behaviors and selected communicators (Budd in Bungin 2005:175). According to Neuman (2006: 322), content analysis is a technique for gathering and analysing the content of text. In this case, content refers to any word, meaning, image, symbol, idea, theme, or other form of communication that can be communicated. This study uses content analysis techniques in purpose of obtaining complete description of various sources, such as text and interviews on business analysis, governance and risk management in Fintech's business so that eventually the data analysis results can be mapped to obtain research output in form of design model for Fintech's governance and risk management.

\section{FINDINGS AND DISCUSSION}

\section{MSMEs Readiness towards online-based financial services offered by Fintech}

MSMEs play a very significant role in creating new job opportunities and economic development. MSMEs take a considerable spot in the economy, especially in private sector around the globe. 


\section{Figure 5 : Survey Results of society's acknowledgement of Fintech}

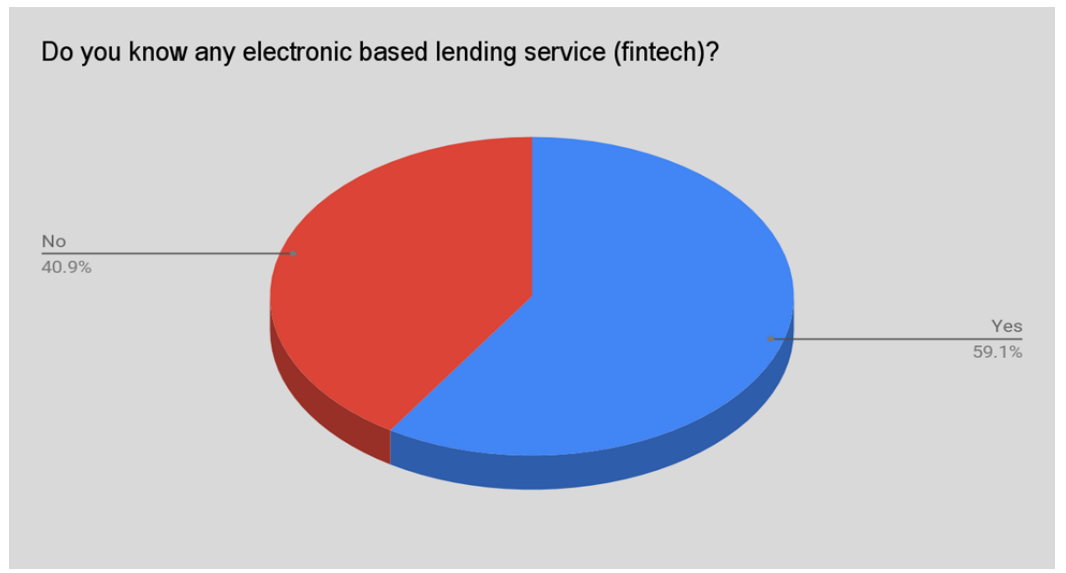

These results show that as much as $59.1 \%$ of the society (MSME) in Malang city already acknowledge Fintech. While 40.9\% of MSME businesspeople are still not familiar with Fintech business model.

\section{Figure 6: Survey Results of MSME Readiness on Fintech Services}

Are you ready to use electronic based lending service (fintech)?

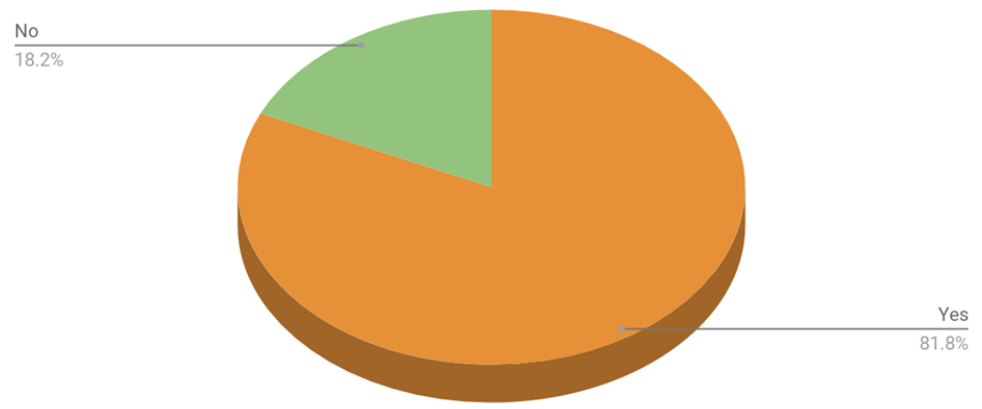

The above diagram shows that the majority of MSME businesspeople or $81.8 \%$ of the respondents are very ready in using Fintech services. This survey results are also supported by interviews of one of MSME businesspeople. In Indonesia Fintech business model has been accepted, belowa are opinions of other SMEs businesspeople in Malang city: 
"We are ready to use the fintech service, because I am open to such a thing. But we need to learn how to do the transaction "

From the obove opinion, it can be seen that in today digitalization era all elements of society can comfortably make use of the internet in every matter, including in business. This statement implies that there is a need for more indepth guidance and socialization, related to the use of fintech in transaction process. This opinion is also in line with the opinion of another entrepreneur:

"Because we used to sell thisngs online so we are used to maybe connect to other people not in person (virtually)".

This opinion supports the previous opinion that business people are familiar with online system and do not feel troubled when transacting without meeting in person with their prospective buyer. It also shows that MSME businesspeople are ready to accept and use services offered by fintech which is supported by the ease access to information technology

\section{Fintech's role in MSMEs development and the national financial system}

Fintech collects capital from retail investors as well as venture capital the it will be used to financing for its consumers. This is an opportunity need to be captured, by MSMEs in particular, to increase the financing amount and upsurge business growth. Fintech role on MSME development is expressed by one of online MSME businesspeople:

"Starting early this year I use Modalku services, it is add my capital thus my business is also getting bigger, I started from small booth in Jl SoukarnoHalatta and I own many branches. Yes actually it's the same as big banks but 
it is easies in its lending. It has very significant role to my business, which is initially small. From Modalku, I don't just get money, but the process is quick and the terms is easy. So it does not cost a lot like if we aplly loan to bank, it's complicated, not to mention costs for this and for that. "

Based on the phrase can be concluded that fintech plays role to increase the source of financing MSME and support the transformation of MSME business. But not only the capital acquired by SMEs but also the businesspeople of MSMEs also get ease in borrowing and lending procedures. Actually fintech role is not different from banking institution that is as financial intermediary. But the difference is that fintech provides easy access to capital for MSMEs businesspeople than conventional banks.

Fintech role in MSMEs development is considered very good in which survey shows the following results:

\section{Figure 7: Survey Results of Fintech Role in MSME development}

Do you think fintech play an important role in MSMEs development?

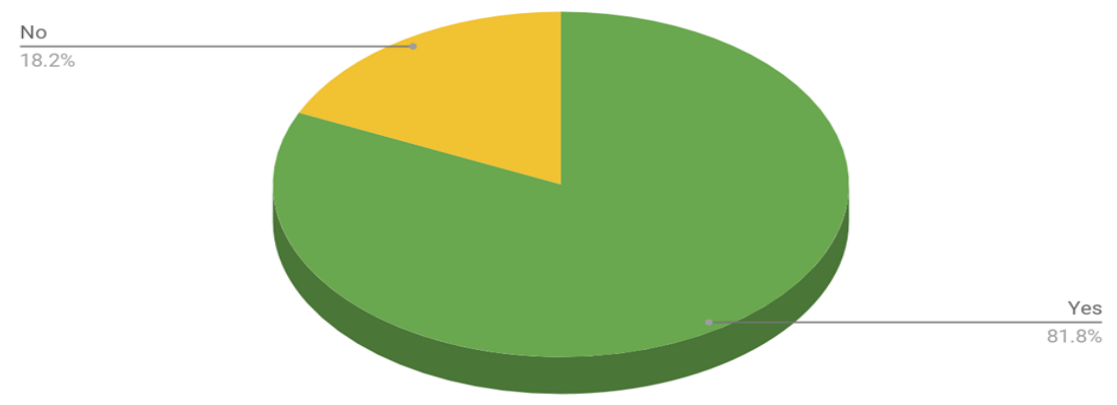

As many as $81.8 \%$ of respondents stated that fintech play a role in MSME development. The trust factor is the main key to the development of fintech business, one way to keep people's trust in this business is to set rules/ 
regulations. The regulation not only serves to maintain the trust of public or users of fintech services, but also pays attention to fintech sustainability (Artajasa, 2016). This is in accordance with the opinion of an economist who is also part of the BI regulator:

"I think his fintech should still be involved in the corridor of banking financial institutions".

This statement emphasizes that Fintech is part of the national financial system. Fintech, which is engaged in lending and borrowing services or P2P lending, is an intermediary institutions that connects investors to MSMEs. This requires fintech to comply with all rules issued by OJK and BI.

\section{Figure 8: Survey Results of Fintech in Easy Transaction}

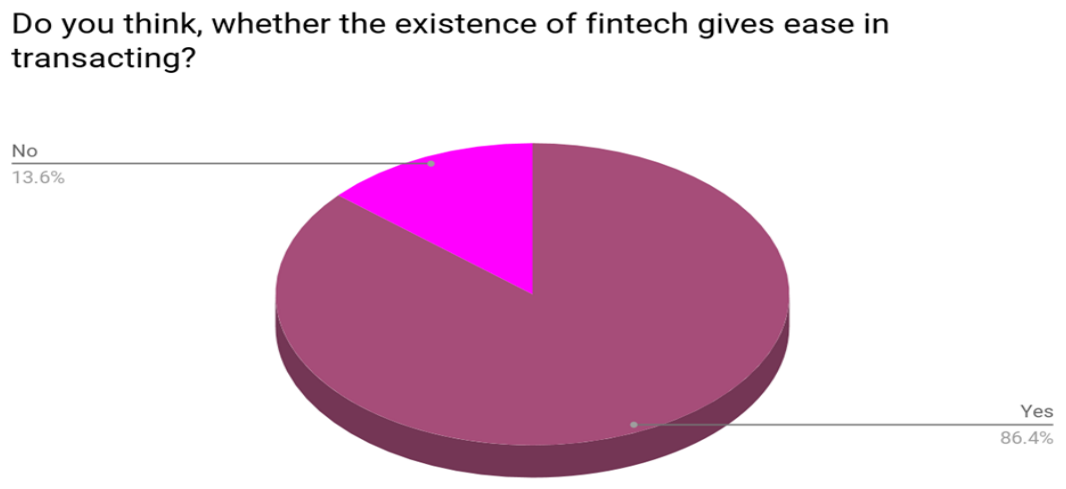

The above diagram shows that $86 \%$ of respondents think hat fintech will provide ease in transacting. The results of this survey are reinforced by the opinion of one regulator stating that fintech will not threaten other financial institutions such as banks, as follows: 
"I don;t think so, in my opinion, from our side, we often discussed how to make our payment system more efficient, but Indonesia is in implementing context "

This opinion indicates that fintech will not be a threat to other financial institutions, even fintech will provide a convenience in payment system. In the future fintech will provide an efficient payment system than the existing one. The convenience offered by fintech will make people comfortable in using its service.

\section{Model Design of Fintech Governance in Providing Financial Services for MSMEs}

The IT Governance perspective breaks down its rules into improvements in information security and minimization of IT risk. Therefore, management of financial institution seeks to find an aggressive or proactive form of IT Governance, aimed to create a value for stakeholders (Inaba, 2016). So in this context it is possible to have flexibility in fintech governance practices aimed at value creation.

Financial technology that provides financing services to MSMEs in form of peer to peer lending has the characteristics of an intermediary institution, such as banking, has a high level of need for governance, as submitted by the informants, academic in the field of fintech:

"Because fintech peer-to-peer lending to get funds from investors, it means that fintech must have governance to be trusted investors first"

The statement emphasizes that the type of P2P Lending platform, that collects funds from people who are over-funded and disbursed to people in need of funds, requires governance to run their business processes. Investors who invest their 
funds must have a trustworthiness for this platforms in managing their funds, so protection measures are required for investors.

Governance model of P2P Lending can not be equated to corporate governance in general, given the differences in business processes between the two as presented in the interview quote of the fintech informant 1 :

"So there are structural differences where there is a possibility that the fintech can not adopt the existing policies in the banking system because of its balance sheet structure".

The statement emphasizes that the fintech business structure in the funding field can not be equated to the conventional bank due to the difference in its balance sheet structure. Fintech particularly peer to peer lending emphasizing data digitization poses many specific challenges related to cybersecurity, data reliability, and specific information technology risks (PWC, 2016). Companies that have been digitized have more complex processes and have rapid changes with unique conditions, thus the need to implement a governance that is more focused on implementing digital business needs to be improved (ISACA, 2015).

Planning of fintech governance by adopting the IT governance model which is developed by IT Governance Institute is a good solution. Here's an opinion from academics:

"The IT governance model created by IT Governance Institute is by far the best and fits the best practice guide in today's digital business world"

The statement explains IT governance model can be a best practice guide for digital business, not to mention financial technology. One of the academics revealed:

"So the success of fintech is how to use that information, big data" 
The above phrase suggests that big data is an important part of fintech business operations. Therefore, the design of fintech governance model in this study incorporates the big data component as a resource that supports the creation of information technology-based governance for fintech.

The main focus of IT governance area according to IT Governance Institute (2015) consists of strategic alignment, value delivery, resource management, risk management, and performance measurement. Based on interviews and content analysis, this study adopts IT governance area in fintech business governance model because the goal of IT Governance is to create value business for stakeholders by utilizing technology. IT governance is not a onestage evaluation nevertheless it can be an activity of continuous improvement and evaluation in rapidly changing technological environment (ISACA, 2015). Here is an overview of fintech governance model of financing business:

Figure 9: Governance model of Financial Technology in Financing Business

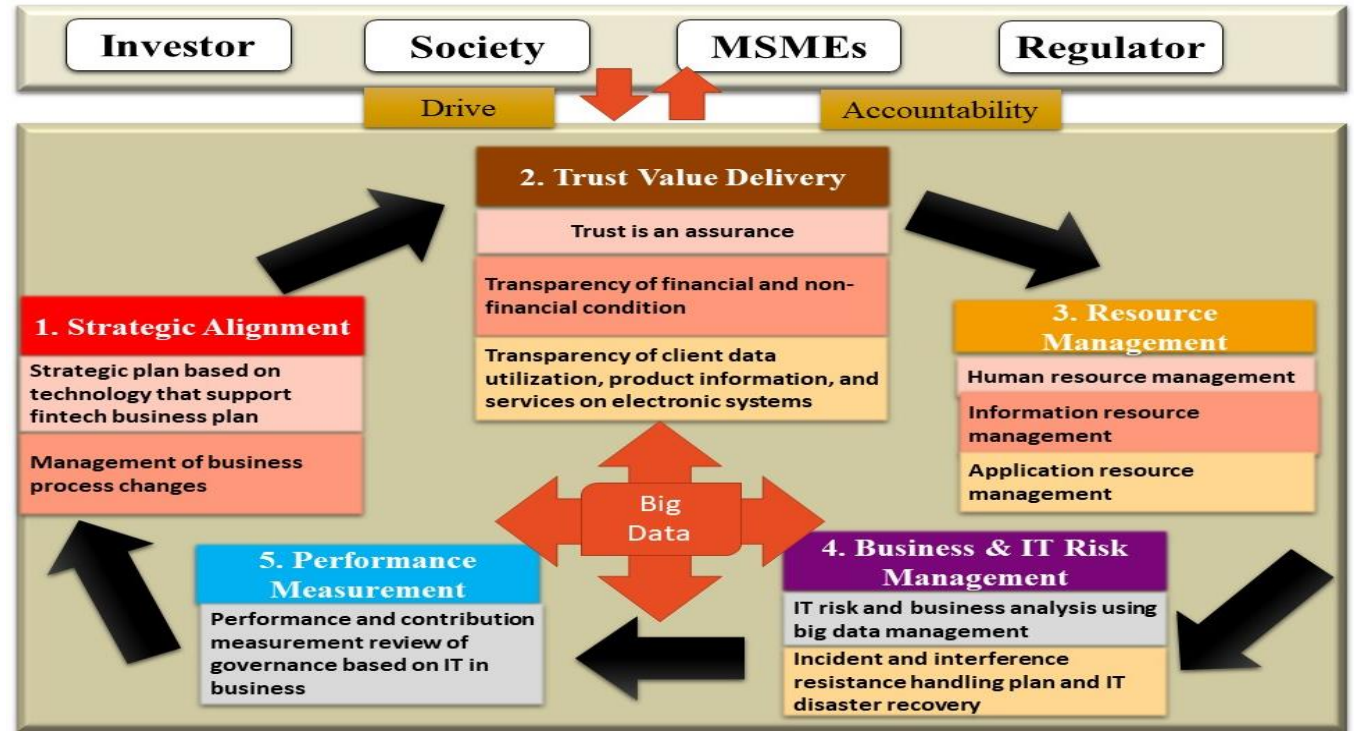

Source: Writer

The governance consists of five areas, namely strategic alignment, trust value delivery, resource management, business \& IT risk management, and Vol. 26, No. 2 December 2018

(c) Centre for Indonesian Accounting and Management Research

Brawijaya University 
performance measurement. In fintech governance model, main stakeholders such as investors, communities, MSMEs and regulators are key drivers of governance in fintech business model.

\section{Model Design of Fintech Risk Management in Providing Financial Services for MSMEs}

The need to strengthen risk management practices is a valuable lesson in times of financial crisis happened to financial and non-financial institutions (OECD, 2016). Results of this study indicate that the actual fintech business risk is not much different from the risks faced by conventional financial institutions. This is in accordance with the results of interviews with one of the academics who pursue the field of fintech:

\footnotetext{
"Actually the risks are almost the same as traditional financial businesses. They face a credit risk. They face liquidity risks, operational risks which may be due to overly high operating expenses. They also face policy risks, so if there is a change in policy from the Indonesian financial services authority that regulates more specifically there will be a change. "
}

The phrase indicates that the risks faced by fintech business are more or less the same as the risk of a bank financial institution as shown in Figure 10 


\section{Figure 10: Business \& IT Risk Management}

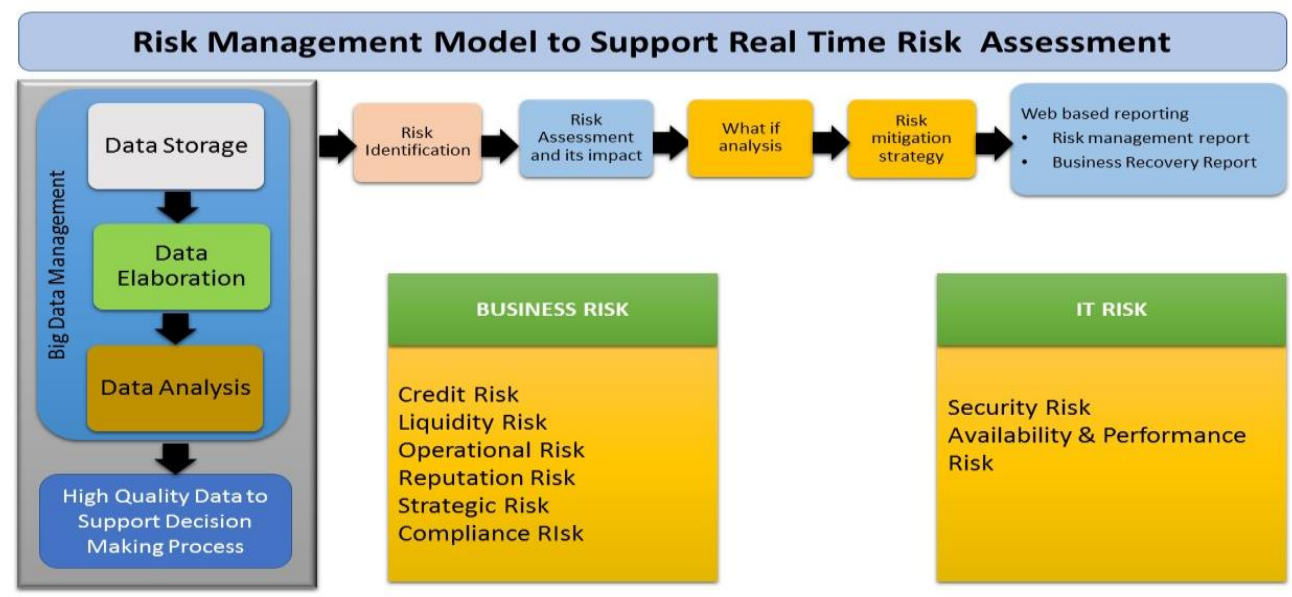

Source: writer

Figure 10 illustrates that fintech has business and IT risks, that need to be well managed. Business risk consists of credit risk, operational risk, reputation risk, strategic risk, and compliance risk, while IT risk consists of security risk, availability risk, implementation risk, and compliance risk. The figure also shows the management flows of risk management for business and IT risks faced by fintech.

In conducting risk management, in analyzing the risks that management needs to mitigate in today's digital era, the best effort is by using big data analysis (Tanzil, 2017). This was conveyed by academic informants as follows:

"The most important keyword in fintech context is how fintech manager can take advantage of big data. In order to minimize cost on fintech, all that can be done is technological innovation"

The statement confirms that big data plays an important role in the fintech business. The above phrase also indicates that by using big data, fintech can 
minimize transaction cost then big can also be implemented as an integrated part of fintech both governance and risk management.

On the other hand, big data analysis can provide real time and useful information that will help directors make quicker and better decisions, not just by intuition (Accenture, 2017). By using big data, fintech is able to implement real time risk management process, that ultimately minimize transaction costs and any costs arise in fintech risk management process. In addition, by using big data, fintech will be able to create good governance and risk management, including supporting accountability through web based reporting and creating value for stakeholders, including being able to play an alternative source of sustainable funding for MSMEs.

\section{CONCLUSION AND SUGGESTION}

Research result shows that nowadays MSMEs doers state their readiness in making use of financial service provide by fintech. Research result shows that the majority of MSMEs doers or about $81,8 \%$ of total respondents are absolutely ready in using Fintech's service. In this case, regulator needs to consider socialization for MSMEs related to the use of fintech in transaction process to optimize the role of fintech as alternative financing source for MSMEs.

Research result also shows that Fintech has significant role in the development of MSMEs, in which it is similar to conventional financial institution that functions as intermediary institution. Research result shows that $86 \%$ of respondents think the existence of fintech will provide convenience in transaction.

Model design of fintech governance and risk management in this research adopts IT Governance framework. Beside that big data management also becomes part of model design of fintech business governance in this research as 
resource that supports the creation of information technology based governance for fiintech, and in the end will support fintech in increasing efficiency and create value for stakeholder. Other important research result is related to model design of risk management which starts with big data management and also big data analytics to support decision making based on qualified data and not intuition, therefore the process can make it easier for supporting the real-time risk assessment based on information technology and decrease cost of regulation.

\section{Suggestion}

Suggestions for further research are as follows:

1. Using quantitative approach in data analysis in order to generalize research result.

2. Advanced survey approach to gain data in order to generalize research result.

3. Expanding the research scope related to the disclosure which have to be conducted by fintech in supporting the implementation of governance and risk management. 


\section{REFERENCES}

Accenture. 2017. Exploring Next Generation Financial Services: The Big Data Revolution. www.accenture.com, accessed on October $1^{\text {st }}, 2017$

Ancri, C. (2016). Fintech Innovation: An Overview. Board Of Governors Of The Federal Reserve System

Artajasa. (2016). Fintech Digital Economy Implementation Supporter in Indonesia. www.artajasa.co.id, accessed on September $29^{\text {th }}, 2017$

Bank of Indonesia. (2016). Financial Technology (Fintech): Analysis of Indonesia's Opportunities in Digital Economy Era from Infrastructure, Technology, Human Resources, and Organizer and Supporter's Regulation of Payment System Service Aspect. Presented in Researchers National Science Meeting, Bogor, July $28^{\text {th }}, 2016$

Bungin, Burhan, 2005. Communication, Economy, and Public Policy and other Social Sciences Quantitative Research Methodology, First Edition, First Copy, Prenada Media, Jakarta

Chandarana, P. \& Vijayalakshmi, M. (2014). Big Data analytics frameworks. ieeexplore.ieee.org

Freeman, R.E. and J. McVea. 2001. A Stakeholder Approach to Strategic Management. http://papers.ssrn.com/, accessed on July $3^{\text {rd }}, 2017$

Ghozali, Imam and Anis Chariri. 2007. Theory of Accounting-3 ${ }^{\text {rd }}$ Edition. Publishing House of Diponegoro University. Semarang.

ISACA. (2015). IT Governance: Developing a successful governance strategy. www.isaca.org, accessed on September $19^{\text {th }}, 2017$ 
IBM. (2017). Big Data. https://www.ibm.com/, accessed on August 31 ${ }^{\text {st }}, 2017$

Koentjaraningrat. (1993). Community Research Methods $3^{\text {rd }}$ Edition. Jakarta: Gramedia

Linangkung, E. (2017). Fintech's Transaction in Indonesia on 2016 Reached IDR 199 Billions. www.ekbis.sindonews.com, accessed on September $\underline{1^{\text {st }}, 2017}$

Moleong, J Lexy. (2009). Qualitative Research Method. Bandung: PT. Remaja Rosdakaya

Mulyani, Sri. (2016). Fintech becomes opportunity for UMKM (Micro, Small, Medium Enterprises). Kompas Newspaper 8/8/2016.

Neuman, W.L. (2006). Social Research Methods: Qualitative and Quantitative Approach, 6th ed. Boston: Allyn and Bacon.

OECD. (2014). Risk Management and Corporate Governance. www.oecd.org, accessed on September $8^{\text {th }}, 2017$

OJK. 2016. Specific Challenge of Fintech Industry. Session Summary published at Indonesia Fintech Festival and Conference 2016

PWC. (2016). Indonesia Fintech Festival \& Conference 2016:| Session Summary. Jakarta: McKinsey Company

Safira, F. (2016). Fintech Ecosystem in Indonesia. https://swa.co.id, accessed on August $12^{\text {th }}, 2017$

Scott, D.H. 2007. Strengthening the Governance and Performance of StateOwned Financial Institutions. Policy Research Working Paper 4321. The World Bank 
Subramanyam, KR and John, J. Wild, 2010. Financial Report Analysis, Book One, $10^{\text {th }}$ Edition, Salemba Empat, Jakarta.

Tanzil, J. (2017). Big Data Analysis in Bisnis. KAP Tanzil Business Magazine, Januari 2017 edition. 